\title{
X-Ray Computed Tomography Analysis of Sajau Coal, Berau Basin, Indonesia: 3D Imaging of Cleat and Microcleat Characteristics
}

\author{
Ahmad Helman Hamdani \\ Faculty of Geology, University of Padjadjaran, Jalan Raya Bandung Sumedang Km 21, Jatinangor, Bandung 45363, Indonesia
}

Correspondence should be addressed to Ahmad Helman Hamdani; ahmad_helman_pgp@yahoo.com

Received 24 March 2015; Revised 31 May 2015; Accepted 4 June 2015

Academic Editor: Robert Tenzer

Copyright (C) 2015 Ahmad Helman Hamdani. This is an open access article distributed under the Creative Commons Attribution License, which permits unrestricted use, distribution, and reproduction in any medium, provided the original work is properly cited.

\begin{abstract}
The Pliocene Sajau coals of the Berau Basin area have a moderately to highly developed cleat system. Mostly the cleat fractures are well developed in both bright and dull bands, and these cleats are generally inclined or perpendicular to the bedding planes of the seam. The presence of cleat networks/fractures in coal seam is the important point in coalbed methane prospect. The 3D $\mathrm{X}$-ray computed tomography (CT) technique was performed to identify cleats characteristics in the Sajau coal seams, such as the direction of coal cleats, geometry of cleat, and cleats mineralization. By CT scan imaging technique two different types of natural fractures observed in Sajau coals have been identified, that is, face cleats and butt cleats. This technique also identified the direction of face cleats and butt cleats as shown in the resulting 3D images. Based on the images, face cleats show a NNE-SSW direction while butt cleats have a NW-SE direction. The crosscutting relationship indicated that NNE-SSW cleats were formed earlier than NW-SE cleats. The procedure also identified the types of minerals that filled the cleats apertures. Based on their density, the minerals are categorized as follows: very high density minerals (pyrite), high density minerals (anastase), and low density minerals (kaolinite, calcite) were identified filling the cleats aperture.
\end{abstract}

\section{Introduction}

Coal is an important source of energy in many parts of the world. Coal is an important source and reservoir rock from which natural gas is formed. Coal is a sedimentary rock with complex polymeric material and dual porosity. The permeability and producibility of coalbed methane reservoir are influenced by distribution of pore and fractures/cleats.

The CBM accumulation, retention, and recovery involve mechanisms that are significantly different from those involved in the concentration of conventional gas reserves. Thus, the pore structure and cleats distribution are very important for gas flow pathway. There are three known gas flow mechanisms in coal $[1,2]$ : (1) desorption of gas from coal surface inside the microspores; (2) diffusion of gas through microspores as governed by Fick's law; and (3) Darcy flow through the cleat system, natural fracture network in the coal to the wellbore. However, it should be remembered that various types of minerals can fill cracks and when cracks are filled with minerals, CBM permeability and productivity will be reduced [3-5]. Cleats are one of the most important internal structures of coal. Cleats play an important role in CBM as they are responsible for determining cleats permeability networks, including cleat mineralization, morphology, and density, and how cleats are related to macroscale fracture permeability $[6,7]$.

Maceral type, rank, and mineral contents influence cleats intensity in coals [8-10]. By nature, coals break easily into small pieces from core and outcrop samples. Therefore, to understand the coal cleat pattern at millimeter scale in coal samples, we need an effective and quick investigation technique that will not destroy samples but can give maximum results. An investigative technique that is increasingly used today is the CT scan tomography $[11,12]$. The ability to perform 3D imaging without destroying samples is one of the advantages of the CT scan method. However, the CT scan method has a limitation as it produces noise and discretization that affect the imaging artifact and beam hardening and 


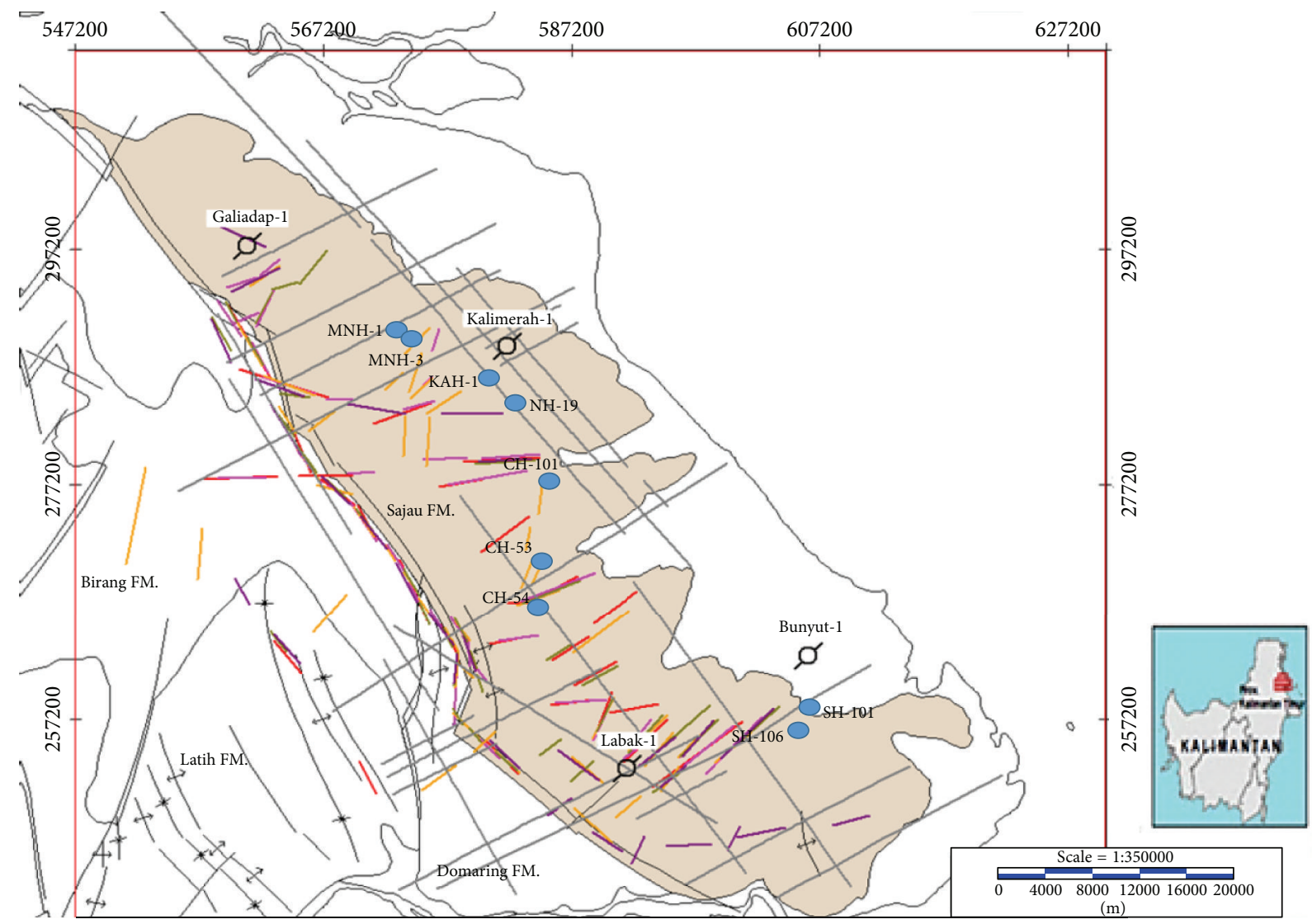

FIGURE 1: The geological map of Tanjungredeb sheet and samples location in Berau Basin.

may thus cause CT number value to be higher than it should be $[13,14]$.

Although in the beginning X-ray CT was mainly used in medicine to image bone structures as introduced by [15], it became soon clear that X-ray CT had a large potential for other applications. Since 1974, the CT scan was developed in many areas of geology, such as paleontology, sedimentology, petroleum geology, and coal geology [16-20]. Computed tomography (CT) is a recent, nondestructive state-of-the-art imaging technique which uses X-ray power to analyze the internal structure of different materials [21, 22]. It works on the basis of density contrast, taking the advantage of different levels of X-ray adsorption. Therefore, by this technique, different materials, interior structure of coals in coals can be identified in $3 \mathrm{D}$ by X-ray computed tomography (X-ray $\mathrm{CT}$ ). In CBM reservoir evaluation, the combined use of X-ray CT techniques has helped to improve understanding about the pores, geometry, and direction of cleats and to examine the evolution of the 3D fracture network during stressing through failure in coals.

Berau Basin is one of the sedimentary basins in Indonesia that have huge coal reserves. Based on a study by [23] the basin has CBM reserves of about 8.4 Tcf. However, there are still insufficient studies of pores, fracture/cleats, and mineralization in coals. In addition, CT characteristics of coals of low rank coal have also yet to be reported. In this research, twelve coal core samples from the potential coal seam in Sajau CBM
Prospect, Berau Basin, were investigated to describe cleats characteristics (including cleats direction and cleats mineralization). The aim of this study is to demonstrate capabilities of CT for nondestructive coal characterization, especially for cleat characteristics. The emphasis of this study is to show a new method for the quantification and 3D visualization of cleats orientation and mineralization.

\section{Experimental Methods}

2.1. Coal Sample Characteristics. To achieve the aim of this research, 12 (twelve) fresh oriented coal blocks were directly collected from shallow well drilling in the Kasai, Mangkupadi, and Tanah Kuning coal mining areas in Sajau CBM Prospect, Berau Basin (Figure 1). All core samples were CTscanned prior to coal quality and mercury injection capillary permeability (MICP) routine tests.

The coals selected for the research (Table 1) had a similar rank degree, that is, lignite. The samples also showed a very wide range of porosity, permeability, and mineralogy [24, 25]. The samples were dominated by huminite macerals range from 76.1 to $86.5 \mathrm{vol}$ \% (average $83.81 \mathrm{vol} . \%$ ), followed by liptinite macerals which have an average of 10.70 vol.\% and inertinite macerals (average 5.49\%). The samples' average huminite reflectance was $0.32 \%$, which indicated that the coal was in an immature stage. The X-ray CT directly scanned all cores to determine the cleats network. The coal reservoir (including 
TABLE 1: Sajau coal characteristics, density, porosity, and permeability.

\begin{tabular}{|c|c|c|c|c|c|c|c|}
\hline \multirow{2}{*}{$\begin{array}{l}\text { Mining area } \\
\text { Sample ID }\end{array}$} & \multicolumn{3}{|c|}{ Coal maceral } & \multirow{2}{*}{$\begin{array}{l}\text { Ro } \\
(\%)\end{array}$} & \multirow{2}{*}{$\begin{array}{c}\rho \\
(\%)\end{array}$} & \multirow{2}{*}{$\begin{array}{c}\varnothing \\
(\%)\end{array}$} & \multirow{2}{*}{$\begin{array}{c}K \\
(\mathrm{md})\end{array}$} \\
\hline & $\mathrm{H}(\%)$ & $\mathrm{L}(\%)$ & I (\%) & & & & \\
\hline \multicolumn{8}{|c|}{ Tanah Kuning } \\
\hline MNH-1A & 84.6 & 12.8 & 2.6 & 0.34 & 1.27 & 8.20 & 57.24 \\
\hline MNH-3C & 81.2 & 11.6 & 7.2 & 0.31 & 1.08 & 6.04 & 15.11 \\
\hline MNH-3D & 76.1 & 11.8 & 12.1 & 0.32 & 1.06 & 4.10 & 14.02 \\
\hline MNH-3E & 84.9 & 9.2 & 5.9 & 0.24 & 1.02 & 5.82 & 28.62 \\
\hline KAH-1F & 78.6 & 12.8 & 8.6 & 0.26 & 1.20 & 6.92 & 1.06 \\
\hline NG-19G & 84.1 & 9.8 & 6.1 & 0.26 & 1.12 & 5.08 & 0.41 \\
\hline NG-19I & 88.2 & 8.6 & 3.2 & 0.26 & 1.10 & 5.18 & 1.23 \\
\hline \multicolumn{8}{|l|}{ Mangkupadi } \\
\hline $\mathrm{CH}-54 \mathrm{~A}$ & 84.2 & 11.7 & 4.1 & 0.34 & 1.24 & 5.20 & 1.42 \\
\hline $\mathrm{CH}-53 \mathrm{~A}$ & 86.7 & 9.6 & 3.7 & 0.36 & 1.21 & 3.24 & 14.62 \\
\hline CH-101A & 84.4 & 10.2 & 5.4 & 0.36 & 1.24 & 3.02 & 4.18 \\
\hline \multicolumn{8}{|l|}{ Kasai } \\
\hline SH-101A & 86.5 & 9.4 & 4.1 & 0.38 & 1.27 & 9.92 & 67.21 \\
\hline SH-106A & 86.2 & 10.9 & 2.9 & 0.36 & 1.27 & 12.92 & 128.24 \\
\hline
\end{tabular}

Note. $\rho$ : coal density $\left(\mathrm{g} / \mathrm{cm}^{3}\right), \varnothing$ : coal porosity by MICP (\%), K: permeability by MICP (md), Ro: huminite reflectance (\%), H: huminite (\%), L: liptinite (\%), and I: inertinite (\%).

porosity and permeability) was measured by MICP and the results showed significant differences between these samples; the porosity Sajau coal was of $3.02-12.04 \%$ with the average $11.64 \%$ and standard deviation $2.86 \%$, while the coal permeability ranged from $0.41 \mathrm{md}$ to $128.24 \mathrm{md}$ with an average of about $51.29 \mathrm{md}$ and the standard deviation was $38.69 \mathrm{md}$. The significant differences in the permeability value indicate that the coals were heterogeneous.

2.2. CT Imaging Scans. The X-ray CT is a nondestructive technique which detects the attenuation of X-rays passing through an object and is dependent on bulk density and effective atomic number. The X-ray attenuation coefficient data over the plane were stored in slice. The X-ray attenuation is mapped in Hounsfield units and converted to CT numbers, in each voxel of a CT image of the object, where

$$
\mathrm{CT}_{\text {number }}=\left(\frac{\mu_{c}-\mu_{w}}{\mu_{c}}\right) \times 1000 \text {. }
$$

The $\mu_{c}$ is the calculated X-ray attenuation coefficient and $\mu_{w}$ is the attenuation of water. In this study we used a water phantom for CT number calibration; the CT number is 0 for water (1 gr/cc) and -1000 for air [26, 27].

The CT scans were performed on a Brightspeed Type equipment manufactured by GE Corporation, USA. The Xray source was a $225 \mathrm{kV}$ Fein Focus focal spot, which allowed resolution to fall down to $10 \mu \mathrm{m}$ for an object of $4.8 \mathrm{~mm}$. The detector system was a Toshiba 3D image intensifier from which data are captured and digitized by a CCD digital camera with a spatial resolution. The CT slice thicknesses $(0.3 \mathrm{~mm})$ and slice increments $(0.9 \mathrm{~mm})$ were kept as thin as possible from slice to improve both resolution and contrast. The Mimics software was used for slice visualization of coal.
The CT scan produced images of $512 \times 512$ pixels with a pixel resolution of $50 \times 50 \mu \mathrm{m}^{2}$ of $4.4 \mathrm{lp} / \mathrm{mm}$.

The cylindrical coal sample was placed perpendicular to the sample pads. Further scanning is in azimuth radiation throughout $0^{\circ}$ and $90^{\circ}$. Then, a series of scans were performed several times (slice). At each sample per meter is research sample scanning with a space of $300 \mu \mathrm{m}$. The CT scan process produced a series of 2D images called "slices," which resulted from scanning with the azimuth angles $0^{\circ}$ and $90^{\circ}$; this is due to the image that will be in line with what would be seen if the object is sliced along the plane of the scan. Each slice would record all X-ray attenuation coefficients along the plane of the scan. Data damping was converted to CT number, of which range was specified by the computer system. Generally, CT numbers were listed as values of gray on gray imaging. A series of CT calibrations were used to maximize the signal-tonoise ratio and minimize or eliminate imaging artifacts that might affect interpretation.

The slice set images from CT scans of cylindrical coal samples were made from three directions, $x, y$, and $z$. The scans in cross section of rock core diameter were the $x y$ plane, while scanning in the direction of the axis of the core rock is the result of scanning the $z$-axis. Combined slices of CT scan on the $y z$ and $x z$ planes were saved as a bitmap image and then converted to SegY format. To build the 3D coal image from X-ray CT scan, the CT image had to be converted to the $3 \mathrm{D}$ cleat aperture distribution $[28,29]$ developed. Furthermore, all slices scanned images were analyzed using the $3 \mathrm{D}$ visualization and modeling (Figure 2 ).

\section{Results and Discussion}

The CT scan of the oriented core rock samples performed on the scan axes $x, y$, and $z$ identified two sets of cleats, namely, face and butt cleats. Figure 3 shows the results of the scan 


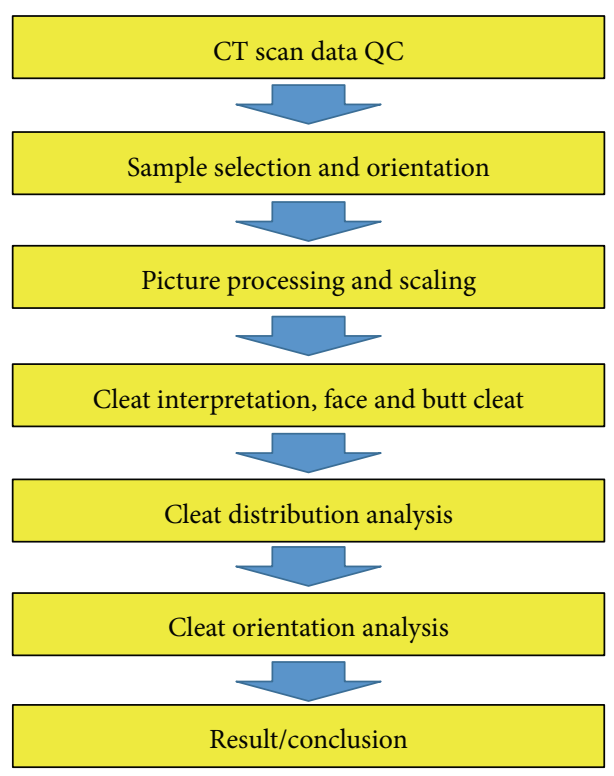

FIGURE 2: Workflow CT scan for 3D reconstruction.

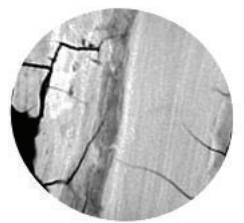

$\mathrm{MNH}-1 \mathrm{~A}$

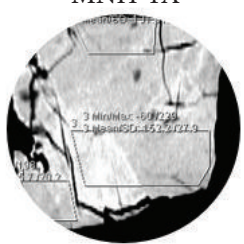

MNH-3E

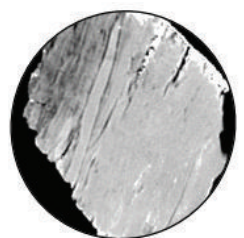

NG-19I

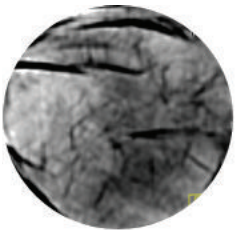

$\mathrm{CH}-101 \mathrm{~B}$

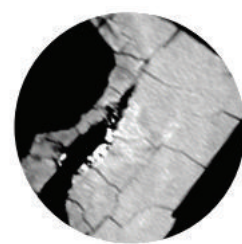

MNH-3C

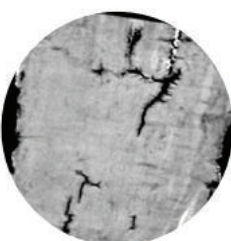

KAH-1F

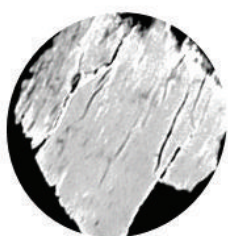

$\mathrm{CH}-53 \mathrm{~B}$

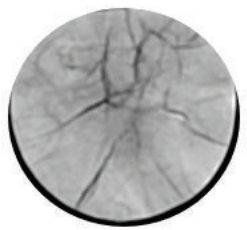

SH-101A

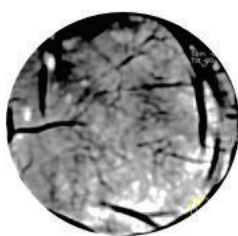

MNH-3D

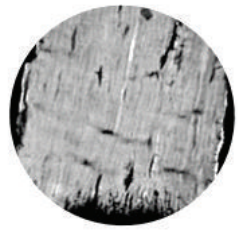

NG-19G

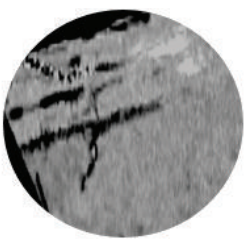

$\mathrm{CH}-54 \mathrm{~A}$

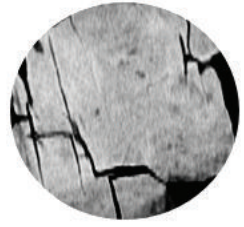

SH-106B

FIgURE 3: The result of CT scan of slice coal on 12 representative coal samples.

axes $x, y$, and $z$ of various rock samples. The face cleat is characterized by an elongated shape and firm, continuous line that has a regular orientation direction, unlike the butt cleat, which has a form of short lines, always abutting with face cleat. Some authors mention that the angle of intersection between the butt cleats and face cleats is $90^{\circ}$ [30]. However, in this study the separation angle is within the range of $81^{\circ}-$ $87^{\circ}$.

Based on the analysis of $3 \mathrm{D}$ cleat orientation work flow (Figure 2), the direction of the orientation of the face cleat 


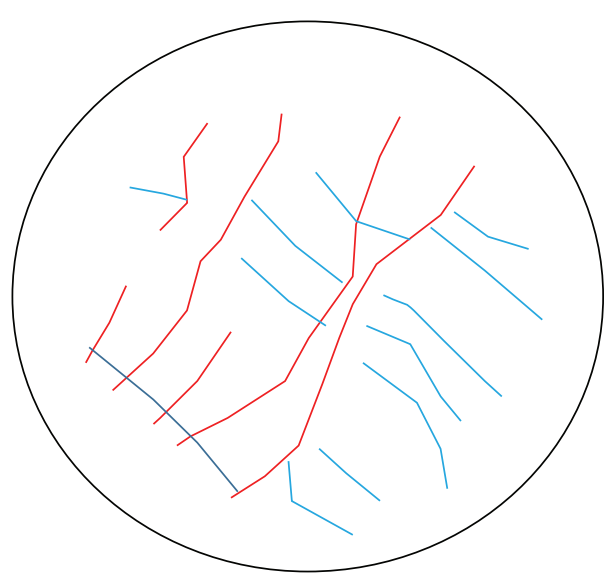

(a)

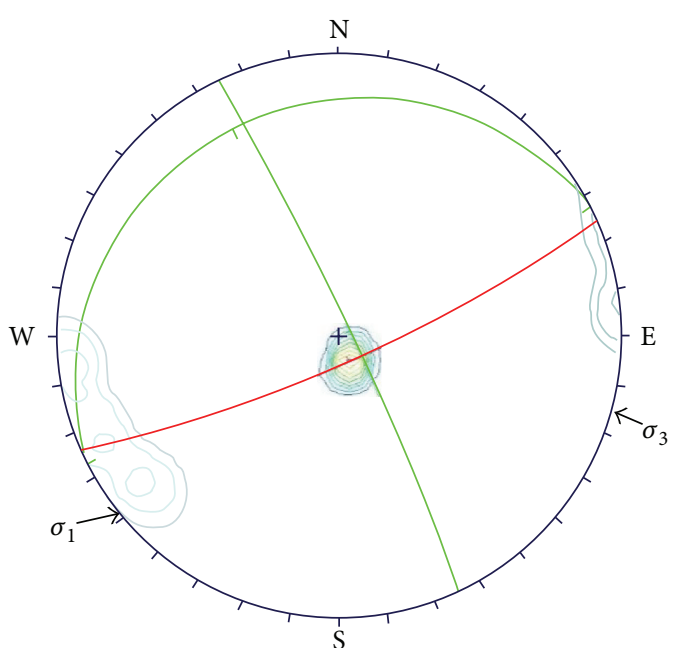

(b)

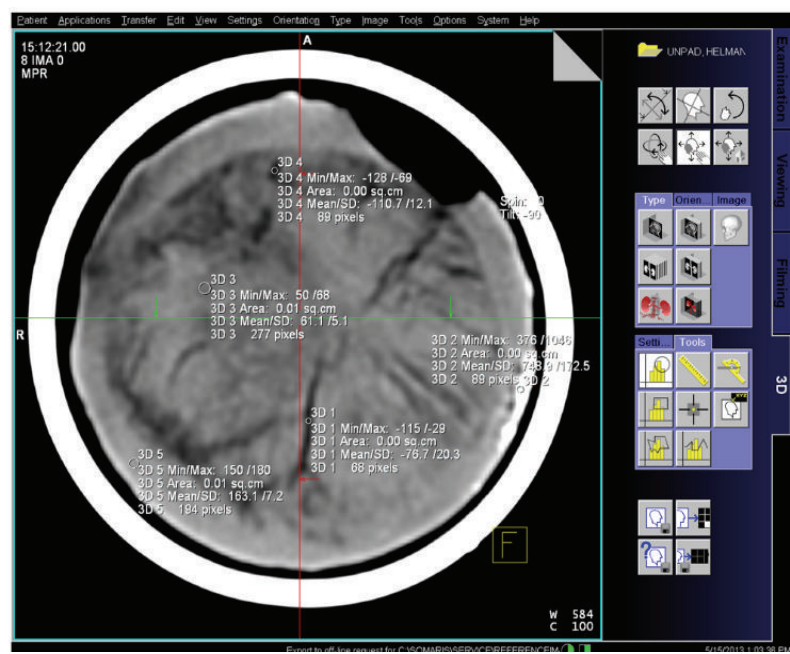

(c)

FIGURE 4: Slice image of SH-101A ( $z$-axis direction), illustrating the CT cleat image (c), cleat interpretation and orientation (a), and Schmidt lower hemisphere equal projection net of cleats orientation relationships (b), showing that $\sigma_{1}$ has NE-SW direction and its scale bar is $10 \mathrm{~mm}$. Two cleat orientations have been identified, that is, NNE-SSW direction (red color) and NW-SE direction (blue color). The cleats with NNESSW direction are abutting in the NE-SW cleats.

and butt cleats could be determined. The various coal samples showed at least two known sets of cleat orientation: NNESSW and NW-SE. The face cleats showed a NNE-SSW direction while the butt cleat had a NW-SE direction. The direction orientation of cleats on core rock showed similarities to that which was measured on the outcrop sample. Measurement directions of cleats on various outcrops within the range of $\mathrm{N} 18^{\circ}-264^{\circ} \mathrm{E}$ belonged to face cleats and those within the range of $\mathrm{N} 62^{\circ}-337^{\circ}$ E belonged to butt cleats. Figures 4 and 5 show the scan results and interpretation of the direction of orientation of the cleats. From the same images it can also be seen that the face cleats in the direction NNE-SSW are abutting the cleats with NE-SW direction. This signifies that NNE-SSW cleats were formed first, followed by the cleats with the NW-SE direction. Then it can be stated that, chronologically, the formation of the cleats followed the NNE-SSW and NW-SE directions.

Tectonically, the structural geology in Berau Basin is influenced by deep-seated NE-SW sinistral Mangkalihat and Maratua. These faults play an important role not only in the arrangement of NW-SE and NNW-SSE fold but also in the cleats direction. The main stress $\left(\sigma_{1}\right)$ of cleats in Berau Basin is NW-SE (see Figure 4). Based on the reconstruction of the structural elements, the relative compression stress of structural geology (fold and fault) also has approximately NESW direction (Figure 5). Therefore, the compressional stress $\left(\sigma_{1}\right)$ of fold, faults, and cleats has a similar direction. Thus, images produced from the CT scan of rock samples can be used to determine the direction (trend) of the main tectonics of regional patterns. 


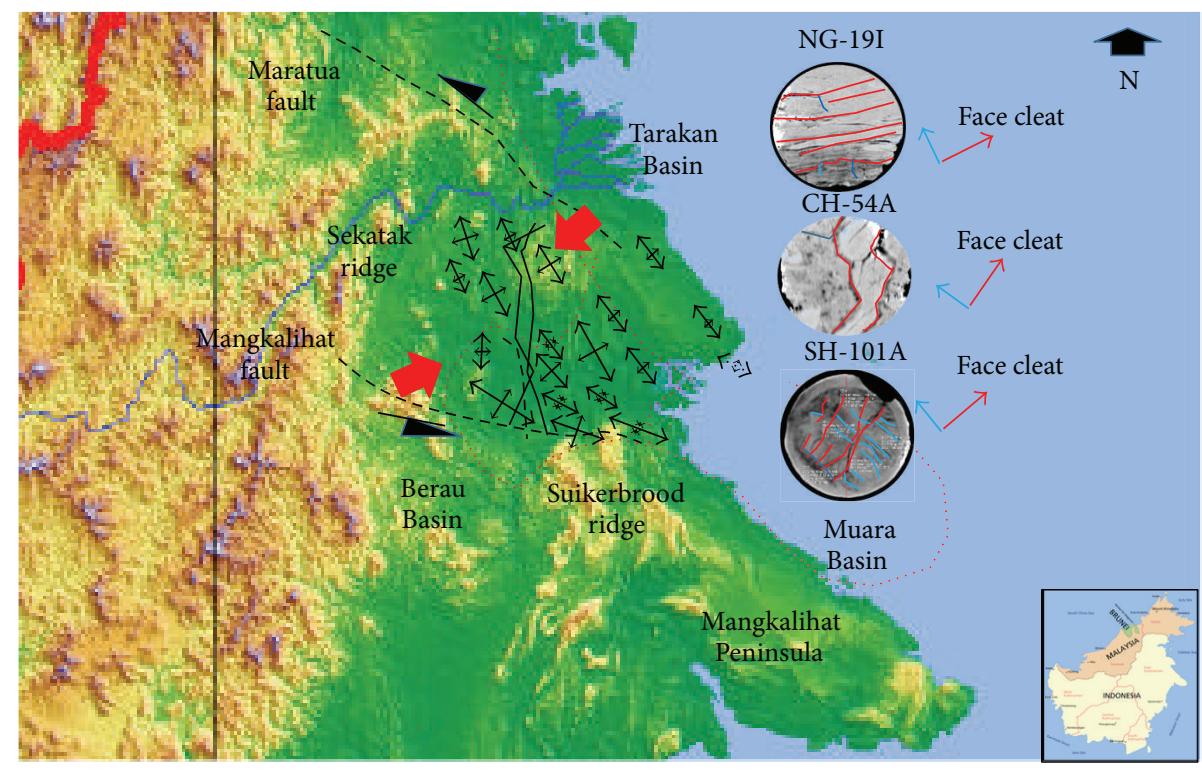

Relative direction of compressional stress

FIGURE 5: Structural geology (folds, faults, and cleats) arrangements in Berau Basin and CT scan image of representative coal samples.

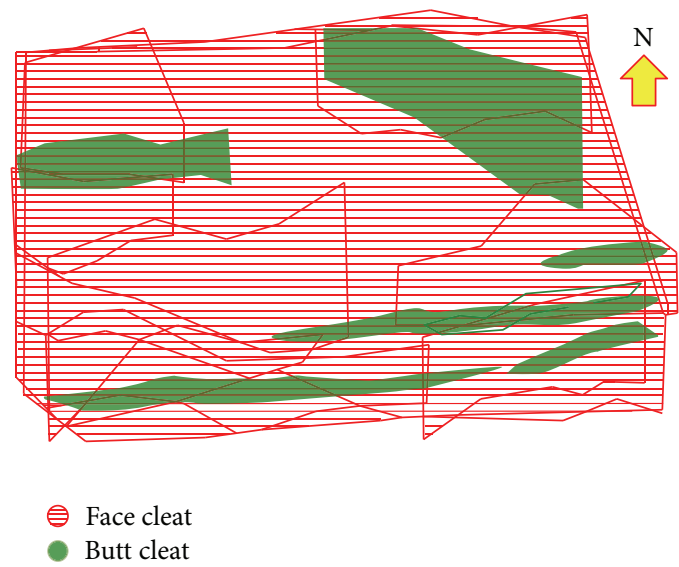

(a)

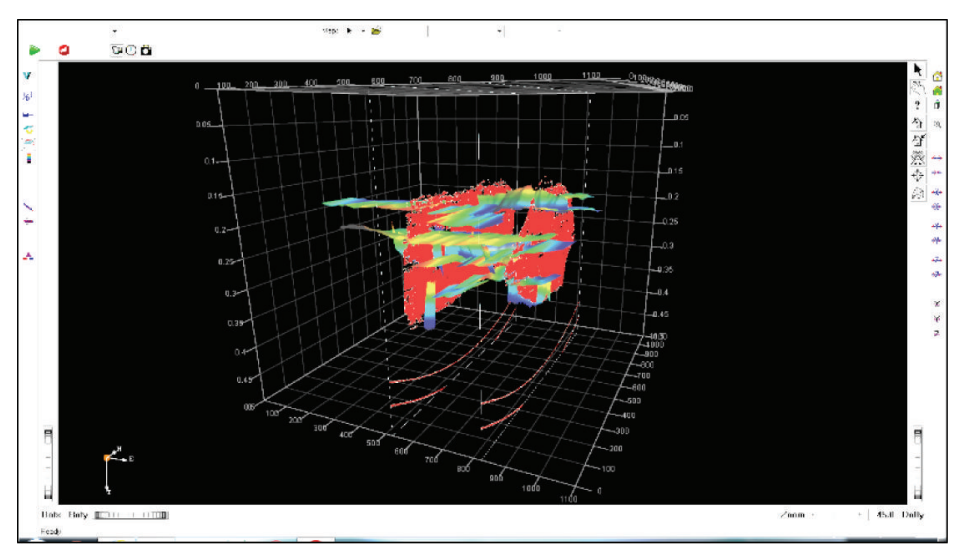

(b)

FIGURE 6: Illustrating 3D reconstruction of the cleats direction (a) from slice image of MNH-1A ( $z$-axis direction); 3D rendering CT scan of MNH-1A (b). Face cleats have NNE-SSW direction (red color and gradational color), and butt cleats have NW-SE direction (green color and solid color).

The 3D reconstruction from slices of core samples of $\mathrm{MNH}-1 \mathrm{~A}$ also indicates that the most dominant directions of orientation of face cleats and butt cleats were NNE-SSW and NW-SE, respectively, as shown in Figure 6. The MNH-1A shows that two set of cleats are recognized: the face cleats and butt cleats. The angles of the face cleats were approximately in the range of $35^{\circ}-45^{\circ}$ on $y-z$ plane, all of which were well developed and well connected. The butt cleats were rare and mostly found on the edge of the samples, and they developed on the $x-z$ plane, with the angles ranging between $22^{\circ}$ and $28^{\circ}$. All cleats had an aperture of approximately $0.2 \mathrm{~mm}$ and a cleat spacing of $0.2-0.82 \mathrm{~mm}$.
By using CT scan measurements, the study has been able to identify at least the following three types of minerals density that fills cleats aperture: very high, high, and low density minerals. Figure 6 shows the CT scan images of the very high density mineral with CT numbers between 450 and $658 \mathrm{HU}$, bright white color, probably pyrite; high density mineral images were shown in white color and have CT numbers $250-410 \mathrm{HU}$, most likely anastase, while low density minerals probably kaolinite and calcite are represented by the grey color, CT numbers being in the range of 180-230 HU. In addition to filling cleats aperture, high density minerals are also scattered in the coal matrix, that is, pyrite in coal matrix 


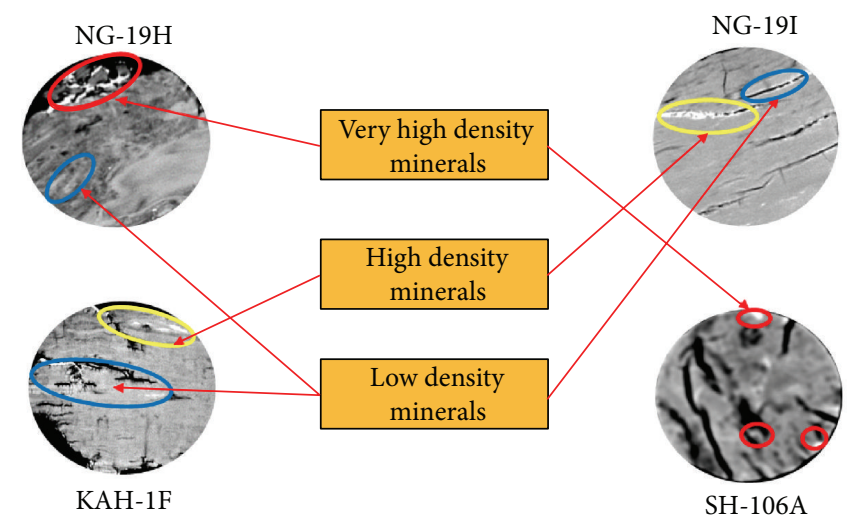

Figure 7: X-section slice images of cleat mineral and their infills as indicated by the X-ray CT technique of coal samples; very high density minerals (bright white, red oval), high density minerals (white, yellow oval), and low density minerals (grey, blue oval).

as seen in SH-106A (Figure 7). A mineral with a low density (kaolinite and calcite) was frequently detected, surrounding high density minerals (pyrite and anastase), such as rims along cleats. In the northern area (NG-19 and KAH-1) the majority of the cleats network was filled with minerals; these minerals could cause permeability level to be low (0.41$1.23 \mathrm{md}$ ). Meanwhile, in the southern part (SH-101A), only a few cleats were filled $(K=128 \mathrm{md})$.

From the discussion above, the $3 \mathrm{D}$ reconstruction of the coal samples can provide cleat network imaging and cleats orientation and mineralization, which will give a different effect on gas permeability. This is very important in evaluating the potential of Sajau coal as a CBM reservoir. Furthermore, the CT scan technique will not damage the sample and does not require special preparation as other types of analysis do. This feature is an advantage when compared with $2 \mathrm{D}$ microscopic examination techniques.

The 3D modeling from CT image also has some associated technical limitations such as image threshold, beam hardening, ring artifacts, partial-volume effects, and lower plane resolution CT. These limitations may induce the uncertainty of the results. Despite these weaknesses, the results obtained from the analysis are still effective for studies of coal cleats characteristics. For future practical applications it is necessary to develop an image processing method that connects the CT data processing between CT images with coal deformation. With such a method, the size of the cleats and deformation density can be calculated from the CT images.

\section{Conclusions}

A total of 12 coals of low rank coal of Sajau Formation in Berau Basin were scanned for 3600 CT slices. These slices were used to reconstruct the $3 \mathrm{D}$ imaging cleats orientation. By means of 3D X-ray tomography, face cleats and butt cleats, as well as their orientation and microcleat generation, were successfully determined based on crosscutting relationships.

Based on the CT scan technique used, the Sajau coals were categorized as a moderately to highly developed cleat system. The cleat fractures were parallel, inclined, or perpendicular to the bedding planes of the seam, and the open spaces were filled with mineral matter, such as kaolinite, calcite, anastase, and pyrite. Crosscutting relationship indicated by X-ray CT scan analysis clearly showed that the NNE-SSW cleats were formed earlier than NW-SE cleats.

\section{Conflict of Interests}

The author declares no conflict of interests.

\section{Acknowledgments}

Mr. Kosasih and Mr. Alit from Laboratory of Coalbed Methane, Lemigas, Jakarta, Indonesia, are acknowledged for making X-ray CT available for this research. Mr. Wegi Oktariadi, from PT. Patriot Wiraperkasa, a coal mine company operating in Berau Regency, is also acknowledged for giving permission to use the borehole cores for CT scan analysis. The author would like to thank anonymous reviewers, who thoroughly reviewed this paper, and their critical comments and valuable suggestions were very helpful in preparing this paper.

\section{References}

[1] C. Ö. Karacan and E. Okandan, "Adsorption and gas transport in coal microstructure: Investigation and evaluation by quantitative X-ray CT imaging," Fuel, vol. 80, no. 4, pp. 509-520, 2001.

[2] T. Ertekin, "Coalbed methane recovery modeling: what we know and what we need to learn," Turkish Journal of Oil and Gas, vol. 1, no. 1, pp. 7-18, 1995.

[3] P. Gamson, B. Beamish, and D. Johnson, "Effect of coal microstructure and secondary mineralization on methane recovery," Geological Special Publication, vol. 199, pp. 165-179, 1998.

[4] C. R. Ward, "Analysis and significance of mineral matter in coal seams," International Journal of Coal Geology, vol. 50, no. 1-4, pp. 135-168, 2002.

[5] J. C. Close, "Natural fractures in coal," in Hydrocarbons from Coal, B. E. Law and D. D. Rice, Eds., Studies in Geology Number 38, pp. 119-132, American Association of Petroleum Geologists, Tulsa, Okla, USA, 1993. 
[6] K. E. Nick, M. W. Conway, and K. S. Fowler, "The relation of diagenetic clays and sulfates to the treatment of coalbed methane reservoirs," in Proceedings of the SPE Annual Technical Conference and Exhibition, Paper SPE 30736, p. 11, Society of Petroleum Engineers, Dallas, Tex, USA, October 1995.

[7] C. I. Pattison, C. R. Fieling, R. H. McWatters, and L. H. Hamilton, "Nature and origin of fractures in Permian coals from the Bowen basin, Queensland, Australia," in Coalbed Methane and Coal Geology, R. Gayer and I. Harris, Eds., vol. 109 of Geological Society Special Publication, pp. 131-150, The Geological Society, London, UK, 1996.

[8] P. F. Kendall and H. Briggs, "The formation of rock joints and the cleat of coal," Proceedings of the Royal Society of Edinburgh, vol. 53, pp. 164-187, 1933.

[9] B. E. Law, "The relation between coal rank and cleat spacing: implications for the prediction of permeability in coal," in Proceedings of the International Coalbed Methane Symposium II, pp. 435-442, 1993.

[10] E. Stach, M. T. H. Mackowsky, M. Teichmueller, G. H. Taylor, and D. R. Chandra, Coal Petrology, Gebruder Borntraeger, Stuttgart, Germany, 1982.

[11] K.-H. A. A. Wolf, F. van Bergen, R. Ephraim, and H. Pagnier, "Determination of the cleat angle distribution of the RECOPOL coal seams, using CT-scans and image analysis on drilling cuttings and coal blocks," International Journal of Coal Geology, vol. 73, no. 3-4, pp. 259-272, 2008.

[12] V. Cnudde and M. N. Boone, "High-resolution X-ray computed tomography in geosciences: a review of the current technology and applications," Earth-Science Reviews, vol. 123, pp. 1-17, 2013.

[13] C. D. Montemagno and L. J. Pyrak-Nolte, "Fracture network versus single fractures: measurement of fracture geometry with $\mathrm{X}$-ray tomography," Physics and Chemistry of the Earth Part A: Solid Earth and Geodesy, vol. 24, no. 7, pp. 575-579, 1999.

[14] J. C. Akin and A. R. Kovscek, "Computerised tomography in petroleum engineering research," in Applications of Computerized X-ray Tomography in Geology and Related Domains, P. Jacobs, F. Mees, R. Swennen, and M. van Geet, Eds., vol. 215, pp. 23-28, Geological Society, London, UK, 2003.

[15] G. N. Hounsfield, "Computerized transverse axial scanning (tomography). Part 1. Description of system," British Journal of Radiology, vol. 46, no. 552, pp. 1016-1022, 1973.

[16] S. Fourie, "The cranial morphologhy of Thrinaxondon liohinus Seeley," Annals of the South African Museum, vol. 65, pp. 337400, 1974

[17] G. C. Conroy and M. W. Vannier, "Noninvasive three-dimensional computer imaging of matrix-filled fossil skulls by highresolution computed tomography," Science, vol. 226, no. 4673, pp. 456-458, 1984.

[18] S. H. Anderson, R. L. Peyton, and C. J. Gantzer, "Evaluation of constructed and natural soil macropores using X-ray computed tomography," Geoderma, vol. 46, no. 1-3, pp. 13-29, 1990.

[19] S. L. Wellington and H. J. Vinegar, "X-ray computerized tomography," Journal of Power Technologies, 1987.

[20] Y. Zeng, C. J. Gantzer, R. L. Payton, and S. H. Anderson, "Fractal dimension and lacunarity of bulk density determined with X-ray computed tomography," Soil Science Society of America Journal, vol. 60, no. 6, pp. 1718-1724, 1996.

[21] M. Van Geet, R. Swennen, and M. Wevers, "Towards 3D petrography: application of microfocus computer tomography in geological science," Computers and Geosciences, vol. 27, no. 9, pp. 1091-1099, 2001.
[22] F. Mees, R. Swennen, M. van Geet, and P. Jacobs, Applications of X-Ray Computed Tomography in the Geosciences, vol. 215, Geological Society of London, 2003.

[23] Advanced Resources International, "Indonesia CBM data package, advanced resources international," Inc. Migas and ADB Report, ARI, 2003, http://www.adv-res.com/.

[24] A. H. Hamdani, E. Sunardi, and A. S. Yoga, "Petrographical characteristics and environmental characteristics and depositional environment of Sajau coal formation in Berau basin, east Kalimantan," in Proceedings of the 10th International Conference on Fluvial Sedimentology (ICFS 10 '13), p. 19, University of Leeds, Leeds, UK, July 2013.

[25] A. H. Hamdani, E. Sunardi, and A. S. Yoga, "The coalbed methane potential from Sajau coal in eastern part of Berau basin, east Kalimantan," International Journal of Scientific Engineering and Research, vol. 3, no. 3, p. 4, 2014.

[26] R. A. Ketcham and W. D. Carlson, "Acquisition, optimization and interpretation of x-ray computed tomographic imagery: applications to the geosciences," Computers \& Geosciences, vol. 27, no. 4, pp. 381-400, 2001.

[27] P. K. Hunt, P. Engler, and C. Bajscrowicz, "Computed tomography as a core analysis tool: applications and artifact reduction techniques," in Proceedings of the SPE Annual Technical Conference and Exhibition, SPE Paper 16952, Dallas, Tex, USA, 1987.

[28] R. A. Ketcham, D. T. Slottke, and J. M. Sharp, “Three-dimensional measurement of fractures in heterogeneous materials using high-resolution X-ray computed tomography," Geosphere, vol. 6, no. 5, pp. 499-514, 2010.

[29] L. A. Lubis, T. Harith, Z. Zahir, M. Noh, and K. Ariffin, "Workflow to reconstruct 3D pore space from 2D CT-scan image of Berea Sandstone," in Proceedings of the 2011 National Geoscience Conference, Johor Bahru, Malaysia, June 2011.

[30] M. Widera, "What are cleats? Preliminary studies from the Konin lignite mine, Miocene of central Poland," Geologos, vol. 20, no. 1, pp. 3-12, 2014. 

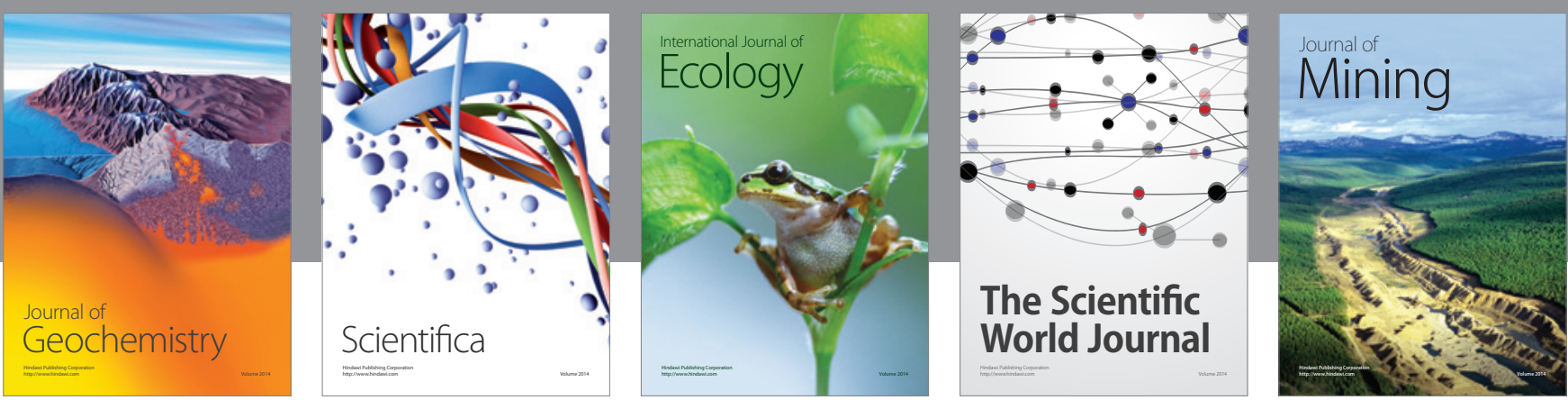

The Scientific World Journal
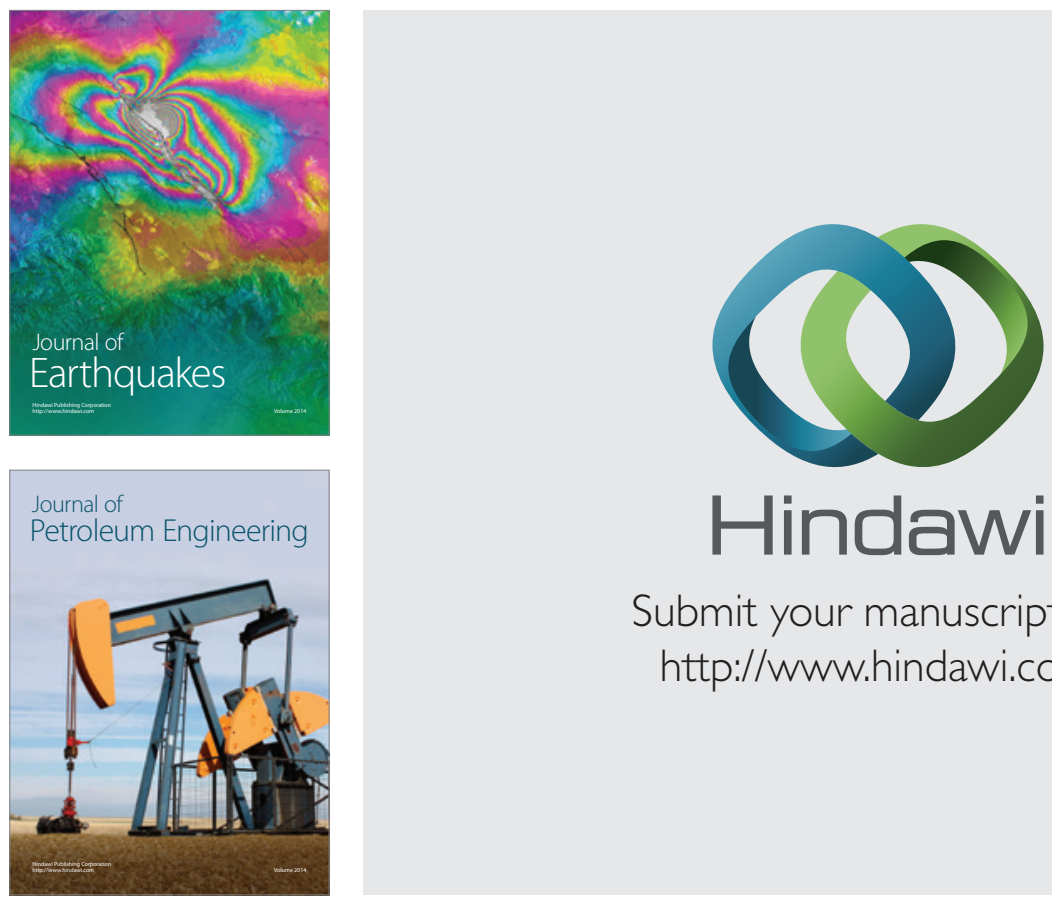

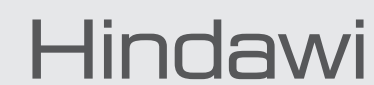

Submit your manuscripts at

http://www.hindawi.com
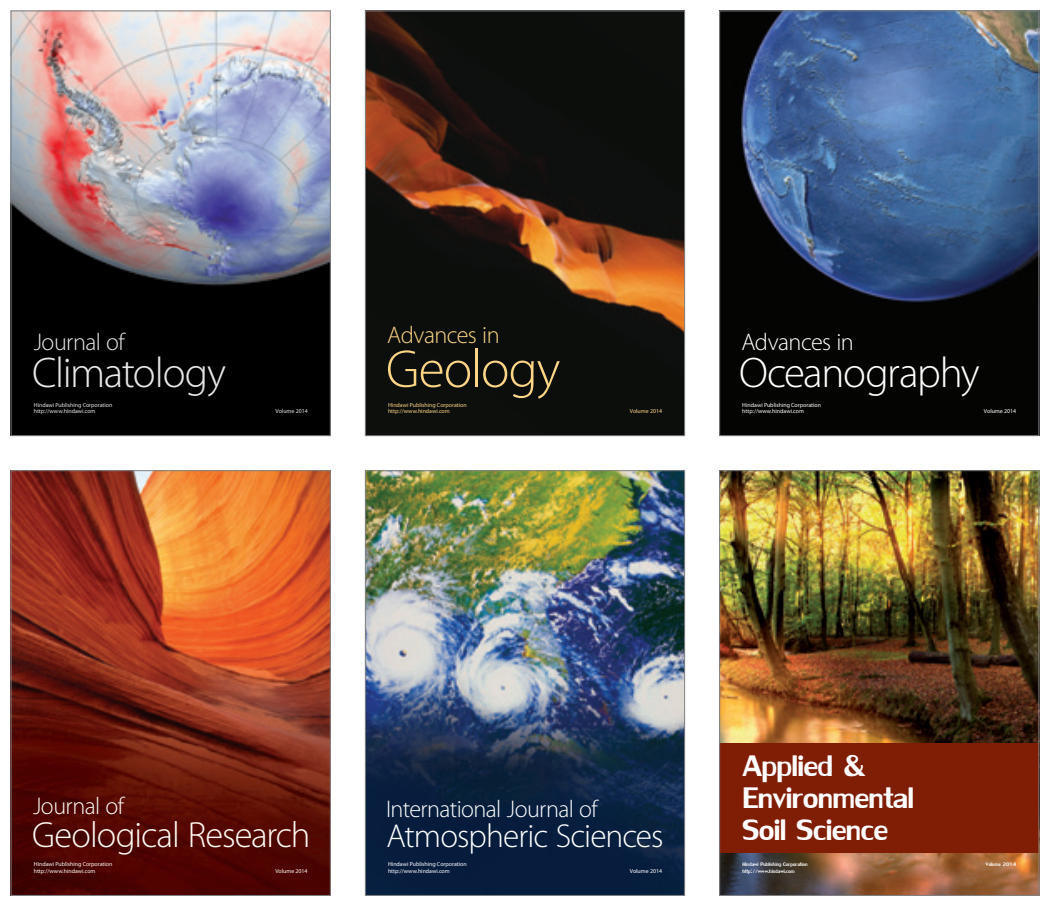
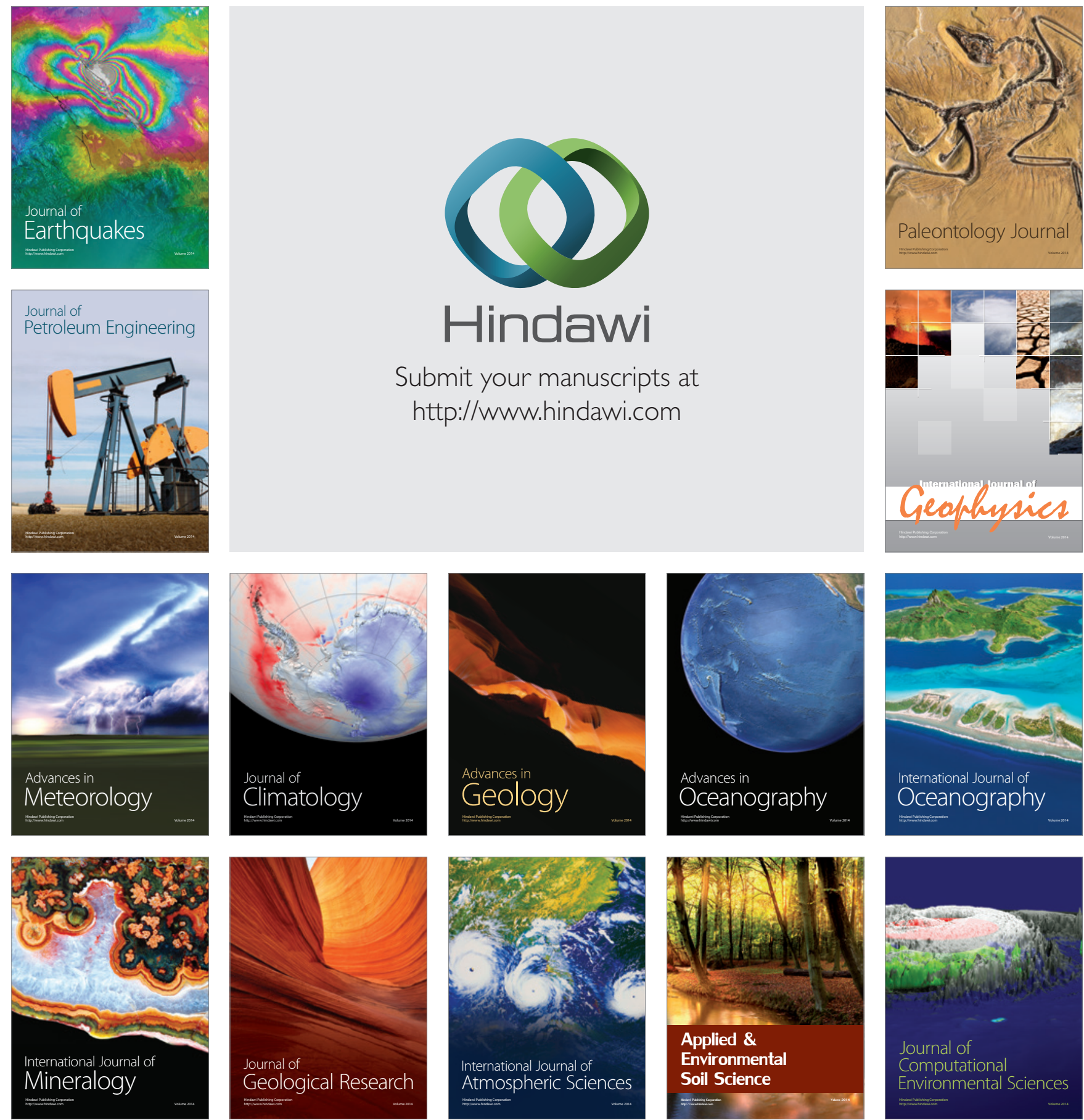